OPEN ACCESS

Edited by:

Kai Lu,

Fujian Agriculture and Forestry

University, China

Reviewed by:

Hao-Sen Li,

Sun Yat-sen University, China

Hamzeh Izadi,

Vali-E-Asr University of Rafsanjan, Iran

Senthil Kumar Nachimuthu,

Mizoram University, India

*Correspondence:

Su Wang

anthocoridae@163.com

Shigui Wang

sgwang@hznu.edu.cn;

sgwang@mail.hz.zj.cn

Specialty section:

This article was submitted to Invertebrate Physiology, a section of the journal

Frontiers in Physiology

Received: 21 June 2020

Accepted: 25 August 2020

Published: 15 September 2020

Citation:

Li Y, Wang S, Liu Y, Lu Y, Zhou M,

Wang S and Wang S (2020) The

Effect of Different Dietary Sugars on

the Development and Fecundity

of Harmonia axyridis.

Front. Physiol. 11:574851

doi: 10.3389/fphys.2020.574851

\section{The Effect of Different Dietary Sugars on the Development and Fecundity of Harmonia axyridis}

\author{
Yan Li', Shasha Wang ${ }^{1}$, Yongkang Liu' ${ }^{1}$, Yuting Lu' ${ }^{1}$, Min Zhou ${ }^{1}$, Su Wang ${ }^{2 \star}$ and \\ Shigui Wang ${ }^{1 *}$ \\ ${ }^{1}$ College of Life and Environmental Sciences, Hangzhou Normal University, Hangzhou, China, ${ }^{2}$ Institute of Plant \\ and Environment Protection, Beijing Academy of Agricultural and Forestry Sciences, Beijing, China
}

The aim of this study was to screen synergistic substances included in existing artificial feeds in order to improve the fertility and survival rate of Harmonia axyridis (Pallas) (Coleoptera: Coccinellidae), an efficient pest predator. To this end, we analyzed the potential effects of glucose and trehalose on the growth, development, and reproduction of $H$. axyridis and evaluated the effect of three different artificial feeds on the energy stress of $H$. axyridis. The artificial diets contained fresh pork liver, honey, sucrose, vitamin $\mathrm{C}$, and royal jelly, which was marked it as Diet1. The glucose was added to diet1, which was marked it as diet2, while adding trehalose to diet1 was marked as diet3. The preoviposition period of $H$. axyridis on Diet 1 was slower than that of Diet 2 and Diet 3. Additionally, the spawning quantity and incubation rate of insects on Diet 2 and Diet 3 were significantly higher than that of those on Diet 1 . Finally, the larval developmental time on Diet 1 was significantly slower than that of Diet 2 and Diet 3. These results indicate that the addition of an appropriate amount of glucose or trehalose may affect positively the growth, development, and reproduction of $H$. axyridis. In addition, further studies showed that ATP, amino acids and fatty acids content in the $H$. axyridis also increased after the addition of the synergistic substance. All these results show that proper adjustment of stored energy anabolic and catabolism is important to maintain the metabolic balance of the insect's entire life cycle and the addition of glucose or trehalose has a certain effect on the life indicators of $H$. axyridis.

Keywords: Harmonia axyridis, artificial diets, glucose, trehalose, fecundity

\section{INTRODUCTION}

Agricultural and forestry crop pests seriously threaten the quality and yield of agricultural production, causing huge economic losses (Hansen et al., 1999). Although chemical control is used for the direct elimination or extermination of agricultural and forestry crop pests, the use of pesticides on a large scale causes severe environmental pollution, endangers human health (Youn et al., 2003; Katsarou et al., 2005; Garratt and Kennedy, 2006), and results in the resistance of many pests (Puinean et al., 2010; Kavi et al., 2014; Bass et al., 2015; Saddiq et al., 2015). It is well-known 
that natural enemy insects are important biological agents in global agricultural ecosystems (Juen et al., 2012; Lu et al., 2012). However, they often face seasonal natural food shortages. In addition, the manual feeding of natural food requires the maintenance of a three-level nutrition chain, which increases both the feeding and the biological control cost (Liu et al., 2013). An artificial diet is the key to avoid the seasonal restrictions of natural food and meet the needs of various experiments. Agricultural pests, such as Hemiptera, Coleoptera, Lepidoptera, and a variety of economic insects, such as the Asian corn borer (Fadamiro et al., 2005) are some of the insect species fed artificial diets.

Harmonia axyridis (Pallas) (Coleoptera: Coccinellidae) is an efficient pest predator (Koch, 2003). A large number of studies have shown that $H$. axyridis is an important insect in the integrated pest management strategy (Brown et al., 2011; Castro et al., 2011; Luo et al., 2014). As early as 1916, $H$. axyridis was released as a biological control insect in orchards, farms, and greenhouses (Michaud, 2002; Majerus et al., 2006; Brown et al., 2011; Van, 2012), but so far there are still natural prey that cannot sustain the ladybugs throughout the year (Zhang et al., 2014). It is difficult to maintain a sufficient $H$. axyridis supply in the biological control of insects, especially when it comes to largescale breeding populations in laboratories (Zazycki et al., 2015). In large-scale insect propagation, feeding aphid diets in captivity is an expensive and time-consuming method (Bonte et al., 2010). Therefore, it is necessary to develop artificial diets that $H$. axyridis can be supplemented with, in order to achieve the low-cost and continuous expansion of this insect that will facilitate the effective control of pests (Cheng et al., 2018). In response to this problem, various artificial insect diets have been exploited and proposed (Cohen, 2001; Castane and Zapata, 2005). Research on artificial diets for $H$. axyridis has ranged from exploring original insect source components such as Tenebrio molitor and Trichogramma dendrolimi Matsumura (Guo and Wan, 2001) to non-insect sources with fresh pig liver as the main component. Many studies have proposed that although insects can be bred with artificial feedstuffs with some success, in many cases they lose their ability to adapt and reproduce, which has led to a delayed development and lower fertility (Denno and Fagan, 2003; Wilder et al., 2011; Schmidt et al., 2012). The previous research, suggested that the main reason for the decline in the hatchability and reproductive capacity of Spodoptera exigua was long-term indoor mating, in subsequent research, these decreases were attributed to irrational feed nutrition (Li et al., 2002).

Studies on Microplitis mediator in bee cocoons have revealed that feeding glucose can enhance the reproductive efficiency and potential of the bees. It has been suggested that the main reason for this is that a carbohydrate food supplement provides mature eggs with the energy they need as they do not need to resort to their lipid reserves to acquire energy; additionally, the accumulation of lipids in the female's body is directly used in oogenesis and egg maturation (Huang et al., 2015). Glucose is the most widely used sugar by insects for energy production and the supply of large molecular precursors and is a signaling molecule in the liver and adipose tissue (Vaulont et al., 2000). As a direct energy substance, glucose can be used better by females for egg maturation (Huang et al., 2015). Some reports showed that glucose metabolism and its regulation are particularly important for termite reproduction; glucose is particularly important for feeding adult females as it provides them with energy for reproduction and promotes egg maturation (Thompson, 2003). The energy metabolism of insects, which is otherwise similar to that of other animals, has a unique feature; the synthesis and utilization of trehalose (Tang et al., 2010). The regulation of trehalose metabolism and the control of glucose utilization are important in terms of energy (Tang et al., 2010). Trehalose can effectively prevent the denaturation and functionality loss of proteins under adverse conditions (Haque et al., 2015). In addition, studies have shown that the trehalose content affects food choices and feeding behavior. The physiological role of trehalose as insects' blood sugar during their reproductive processes has been reported previously (Lu et al., 2019). A parallel relationship between the hemolymph trehalose levels and ovarian maturation was observed, suggesting that trehalose supplies the energy required for the reproductive cycle processes (Huang and Lee, 2011). Trehalose is a readily accessible energy source that can be used as required (Shi et al., 2017).

In addition, studies have shown that the main parts of insects that produce and store glycogen and trehalose are fat bodies, ovaries, and flying muscles (Tang et al., 2012). Trehalose is the energy fuel for vitellogenin ( $\mathrm{Vg}$ ) formation and oocyte maturation (Lu et al., 2019). Therefore, it is speculated that eating artificial feedstuffs with glucose or trehalose could provide insects with sufficient energy to act on the ovary, thereby promoting the development of their ovaries and increasing spawning. The population proliferation of insects is based on individual reproduction, and reproductive success depends on the $\mathrm{Vg}$ synthesis of the fat body and on oocyte development (Tufail and Takeda, 2008; Tufail et al., 2010). Vg is the main storage protein precursor of the ova of many animals, the energy reserve of many ovipara (Zhang et al., 2017), and plays an important role in the reproduction of oviparous vertebrates and invertebrates (Liu et al., 2013).

The aim of this study was to supplement insect diets with potentially synergistic substances while meeting their minimum nutritional requirements. Additionally, we aimed to discover and screen more effective and high-quality artificial feedstuffs for natural enemy insects that would lead to higher proliferation, thereby providing technical support for their release. Based on previous reference on artificial feedstuffs (Yang et al., 2013), we used glucose and trehalose as energy supplying nutrients for insects. By measuring the growth, development, reproductive ability, and substance content indicators in the bodies of $H$. axyridis, we evaluated the potential role of glucose and trehalose on their growth, development, and reproduction.

\section{MATERIALS AND METHODS}

\section{Insects}

Harmonia axyridis individuals were raised in the Key Laboratory of Animal Adaptation and Evolution of Hangzhou Normal 
University. All insects were bred in a growth chamber maintained at $23 \pm 2{ }^{\circ} \mathrm{C}$, with $68 \pm 5 \%$ relative humidity $(\mathrm{RH})$, and a photoperiod of 16:8 h (L: D). H. axyridis individuals were fed Aphis medicaginis at a fixed time every day. After oviposition, the eggs were collected 2-3 times daily and placed in a $7 \mathrm{~cm}$ Petri dish containing filter paper; distilled water was sprayed onto the filter paper once a day to preserve its humidity. After the eggs hatched, we used a writing brush to gently move the hatched larvae into individual larva rearing boxes containing aphids or artificial feedstuffs $(4 \mathrm{~cm} \times 3 \mathrm{~cm} \times 2 \mathrm{~cm})$. It was necessary to keep them alone in order to prevent cannibalism and competition among individuals. After being reared to emergence, the adults (12 females and 8 males in each box) were placed in adult feeding boxes containing aphids or artificial diets. The diet in all feeding boxes was changed once a day and wet cotton balls were replenished.

\section{Preparation of Artificial Diets}

In this experiment, we used the artificial feed formula prepared by Yang et al. (2013) as reference material; we adapted it by optimizing the addition of ingredients and improving their ratio (Yang et al., 2013). Three artificial feed formulae were designed, namely Diet 1, Diet 2 and Diet 3, CK represents Aphis medicaginis used as the control. The raw materials were weighed and mixed according to the number of insects in each group, in order to prepare a semi-fluid feed and were stored in a refrigerator at $-20^{\circ} \mathrm{C}$. For a detailed component analysis of each formula, see Table 1.

\section{Experimental Method \\ Determination of the Tissue and Hemolymph Sugar Contents of $H$. axyridis Larvae}

At least 50 early fourth instar larvae were collected from each of the three groups, which fed with Diet 1, Diet 2, and Diet 3. After having fed for 12, 24, and $48 \mathrm{~h}$, the larvae were placed on ice. After the larval ability decreased, their feet were punctured by a medical anatomical needle. Hemolymph was collected with a capillary tube and transferred to an Eppendorf (EP) tube (Eppendorf, Hamburg, Germany) containing anticoagulant (Wang et al., 2007). Each tube contained the hemolymph of seven larvae. After hemolymph extraction, the tissue of larvae was placed into a new EP tube; each tube contained the tissue of three larvae. Each of the experiments was performed in three biological replicates and three technical replicates.

TABLE 1 | Specific ingredients of the artificial feed formula of the $H$. axyridis.

\begin{tabular}{lccr}
\hline Ingridients & Diet 1 & Diet 2 & Diet 3 \\
\hline Fresh pork liver & $64 \%$ & $64 \%$ & $64 \%$ \\
Honey & $13.5 \%$ & $13.5 \%$ & $13.5 \%$ \\
Vitamin C & $3.5 \%$ & $3.5 \%$ & $3.5 \%$ \\
Sugar & $13.5 \%$ & $13.5 \%$ & $13.5 \%$ \\
Royal jelly & $5.5 \%$ & $5.5 \%$ & $5.5 \%$ \\
Glucose & - & $12 \%$ & - \\
Trehalose & - & - & $20 \%$
\end{tabular}

The above samples were ground with phosphate buffered saline (PBS) and sonicated. Subsequently, $350 \mu \mathrm{L}$ of the supernatant was collected and ultracentrifuged at 20,800 $\mathrm{g}$ for $60 \mathrm{~min}$ at $4^{\circ} \mathrm{C}$. The remaining supernatant was used to determine the protein, trehalose, and glycogen contents. The trehalose content was measured using the anthrone method. Briefly, we took $30 \mu \mathrm{L}$ of the centrifuged supernatant sample, added $30 \mu \mathrm{L}$ of $1 \% \mathrm{H}_{2} \mathrm{SO}_{4}$, placed it in a water bath at $90^{\circ} \mathrm{C}$ for $10 \mathrm{~min}$, and then in an ice bath for $3 \mathrm{~min}$. After adding $30 \mu \mathrm{L}$ of $30 \% \mathrm{KOH}$, the sample was incubated again at $90^{\circ} \mathrm{C}$ in a water bath for $10 \mathrm{~min}$ and in an ice bath for $3 \mathrm{~min}$. Then, $600 \mu \mathrm{L}$ of developer was added and the sample was placed in a water bath at $90^{\circ} \mathrm{C}$ for $10 \mathrm{~min}$ and then cooled in an ice bath. The absorbance of the sample was measured at $630 \mathrm{~nm}$ using a microplate reader. A glucose assay kit (Sigma-Aldrich, St. Louis, MO, United States) was used to measure the glucose content by taking $150 \mu \mathrm{L}$ of $20,800 \mathrm{~g}$ centrifuged supernatant and $20,800 \mathrm{~g}$ of pellet suspension, according to the manufacturer's instructions. After incubation in water bath at $37^{\circ} \mathrm{C}$ for $30 \mathrm{~min}, 300 \mu \mathrm{L}$ of $2 \mathrm{~N} \mathrm{H}_{2} \mathrm{SO}_{4}$ was added to stop the reaction, and the absorbance of the samples was measured at $540 \mathrm{~nm}$ using a microplate reader. For the determination of the glycogen contents, $160 \mu \mathrm{L}$ of supernatant obtained after centrifugation at $1,000 \mathrm{~g}$ was added to $600 \mu \mathrm{L}$ of anthrone sulfate reagent, and the mixture was incubated at $90^{\circ} \mathrm{C}$ for $10 \mathrm{~min}$ and then cooled in an ice bath. The absorbance of the sample was measured at $625 \mathrm{~nm}$ using a microplate reader. The protein content was determined using the BCA Protein Assay Kit (Beyotime, Shanghai, China).

\section{Observation of the Developmental Duration and the Body Weight Index of $H$. axyridis Larvae}

At least 100 eggs were collected from each group. We measured the developmental period from the first instar to the pupal stage and monitored the development of $H$. axyridis every day. At the same time, the body weight of the larvae that fed on different artificial feeds was recorded. Electronic scales (METTLER TOLEDO, Shanghai, China) were used to weigh the first, second, third, and fourth instar larvae. As the larvae were small, 10 larvae that fed on the same feed and were at the same developmental stage were weighed each time. Then, we recorded the average weight of the three groups; the above experiment was repeated three times.

\section{Observations on the Pre-oviposition, Oviposition Rate, and Fecundity of $\boldsymbol{H}$. axyridis}

We collected at least 50 pairs of $H$. axyridis adults from each group. Each group was provided with five feeding boxes for 42 days. The time from the first day of the emergence of $H$. axyridis to the oviposition time was considered as the pre-oviposition. Then, the daily oviposition of adults that had fed on different diets and aphids was counted and recorded. We recorded the average of three breeding rounds as the final spawning result. From each round, we selected approximately 100 eggs and repeated this process three times per group. Then, we calculated the hatchability of the eggs by observing and recording the number of first instar larvae after 1 day of incubation. 


\section{Determination of the Sugar and Substance Contents of $H$. axyridis Adults}

We collected at least 50 pairs of the adults from each group at the beginning of the emergence stage. Then, we measured the sugar and substance contents of females that had fed for 48 and $72 \mathrm{~h}$. The sugar content detection method was the same as the one described in Section "Determination of the Tissue and Hemolymph Sugar Contents of $H$. axyridis Larvae." We used the GLYCERINE kit, the Non-esterified Free fatty acids assay kit (NEFA), and the Total Amino Acid assay kit to measure the glycerine, free fatty acid, and adenosine $5^{\prime}$-triphosphate (ATP) contents. The above kits are collected from Nanjing Jiancheng Bioengineering Institute.

\section{Ovarian Development in $H$. axyridis Adults}

We collected at least 50 pairs of the adults from each group at the beginning of the emergence stage and fed them Diet 1, Diet 2 , and Diet 3. The ovaries of $H$. axyridis that had fed for 3, 5, and 7 days were dissected. The vivisection of female $H$. axyridis was conducted in saline; first, we cut off their wings and head and then we attached the insect bodies to the anatomical box (AGAR dish). Under the Leica EZ4HD stereoscopic microscope (Leica, Wetzlar, Germany), we cut along the middle back of the adults to the end of the abdomen and removed the organs and tissues of non-reproductive systems, such as the digestive tract and the fat body.

\section{Determination of the Relative Expression of the $\mathrm{VgR}$ and Vgs Genes in $\mathrm{H}$. axyridis}

We collected at least 50 pairs of the adults from each group at the beginning of the emergence stage. Ha-rp49 was used as an internal reference gene and detected the relative expression of the $V g R, V g 1$, and $V g 2$ genes in their adults.

First, total RNA was extracted from the adults of $H$. axyridis by a Trizol-based method. Each tube sample was homogenized with $800 \mu \mathrm{L}$ of TRIzol reagent (Invitrogen, Carlsbad, CA, United States) according to the manufacturer's instructions. A Thermo Scientific NanoDrop 2000 UV-Vis spectrophotometer (Thermo Fisher Scientific, Inc., Waltham, MA, United States) was used to determine the RNA quality and quantity. Complementary DNA (cDNA) was synthesized from $1 \mu \mathrm{g}$ of total RNA using the PrimeScript ${ }^{\mathrm{TM}} \mathrm{RT}$ reagent Kit with gDNA Eraser (perfect Real Time) (Takara Bio, Inc., Kusatsu, Japan) according to the manufacturer's protocol.

The cDNA was diluted fivefold for subsequent quantitative real-time polymerase chain reaction (qRT-PCR) analyses. qRTPCR was carried out in $20 \mu \mathrm{L}$ reactions containing $1.0 \mu \mathrm{L}$ cDNA, $10 \mu \mathrm{L}$ SYBR Green Premix Ex Taq (Takara Bio, Inc.), $1 \mu \mathrm{L}$ forward primer $(10 \mu \mathrm{M}), 1 \mu \mathrm{L}$ reverse primer $(10 \mu \mathrm{M})$, and $7 \mu \mathrm{L}$ nuclease free water using the Bio-Rad CFX96 ${ }^{\mathrm{TM}}$ Real-Time PCR Detection System (Bio-Rad Laboratories, Inc., Hercules, CA, United States). Then, we conducted a melting curve analysis (from 60 to $95^{\circ} \mathrm{C}$ ) to ensure the consistency and specificity of the amplified product. All samples were normalized to the threshold cycle value for QHa-rp49 mRNA, which was chosen as an invariant control. Information on the primer sequences of the H. axyridis genes is shown in Table 2.
TABLE 2 | Sequences of qRT-PCR primers for $V g R$ and $V g s$ genes.

\begin{tabular}{lll}
\hline Gene & Forward $\left(\mathbf{5}^{\prime} \mathbf{-} \mathbf{3}^{\prime}\right)$ & Reverse $\left(\mathbf{5}^{\prime} \mathbf{-} \mathbf{3}^{\prime} \mathbf{)}\right.$ \\
\hline HaVgR & TGTAGGAGGCGAAGCAATGAT & TGGGATGTGACAGGGAAATAA \\
HaVg1 & GCAACAGAGTCCGTGGTCTT & GCTGCTTCACCGTTCTTCAA \\
HaVg2 & CAATCAAAACTCAAGCA & GTCAAAAACTGGATGGAC \\
& AGGAGA & AACAA \\
QHarp49 & GCGATCGCTATGGAAAACTC & TACGATITGCATCAACAGT \\
\hline
\end{tabular}

\section{Statistical Analyses}

All the data were analyzed using a one-way ANOVA with the statistical software package version 7.0 (StatSoft, Inc., Tulsa, United States). Multiple comparisons of means were conducted using Tukey's test. Differences between means were deemed to be significant when $P \leq 0.05$. Statistical analysis was performed with STATISTICA 8.0 and Sigma Plot 10.0. The qRT-PCR data were processed using the $2^{-\triangle \Delta C T}$ method (Livak and Schmittgen, 2001).

\section{RESULTS}

\section{Tissue and Hemolymph Sugar Contents of $\boldsymbol{H}$. axyridis Larvae}

The tissue and hemolymph glycogen content after 24 and $48 \mathrm{~h}$ feeding on the Diet 2 and Diet 3 were significantly higher than that of the Diet $1(P<0.05)$ (Figures 1A,D). The trehalose content in the tissues of larvae fed on Diet 1 for 24 and $48 \mathrm{~h}$ Diet 1 was significantly lower than that of the Diet 2 and Diet $3(P<0.05)$ (Figure 1B). The trehalose content in the hemolymph of the Diet 1 was lower than that of the Diet 2 and Diet $3(P<0.05)$ (Figure 1E). The glucose content in the tissues of all groups did not change significantly after having fed for $24 \mathrm{~h}$. However, the glucose level of Diet 1 was significantly lower than those of Diet 2 and Diet $3(P<0.05)$ after $48 \mathrm{~h}$ (Figure 1C). After 12 and $24 \mathrm{~h}$ of feeding, the glucose content in the hemolymph of Diet 1 was significantly lower than that of Diet 2 and Diet 3, while there were no significant differences among the insects of the three groups after they had fed for $48 \mathrm{~h}$ $(P<0.05)$ (Figure 1F).

\section{Developmental Time and Larval Weight}

We observed and recorded the developmental time of the larvae and pupae that had fed on different artificial diets. As is shown in Figure 2, the effect of different diets on the developmental time of the larvae was significant $(P<0.05)$. The developmental times of the larvae fed on of Diet 2 and Diet3 were much shorter than that of Diet 1 (25.8, 24.5 , and 28.1 days, respectively). The developmental time of each of the aforementioned groups was longer than that of the group that fed on aphids, which was about 21.5 days. As is presented in Table 3 , the $H$. axyridis that fed on the three diets were lighter than those that fed on aphids. Additionally, Diet 2 and Diet 3 individuals weighed more than Diet 1 individuals. More specifically, the differences were 

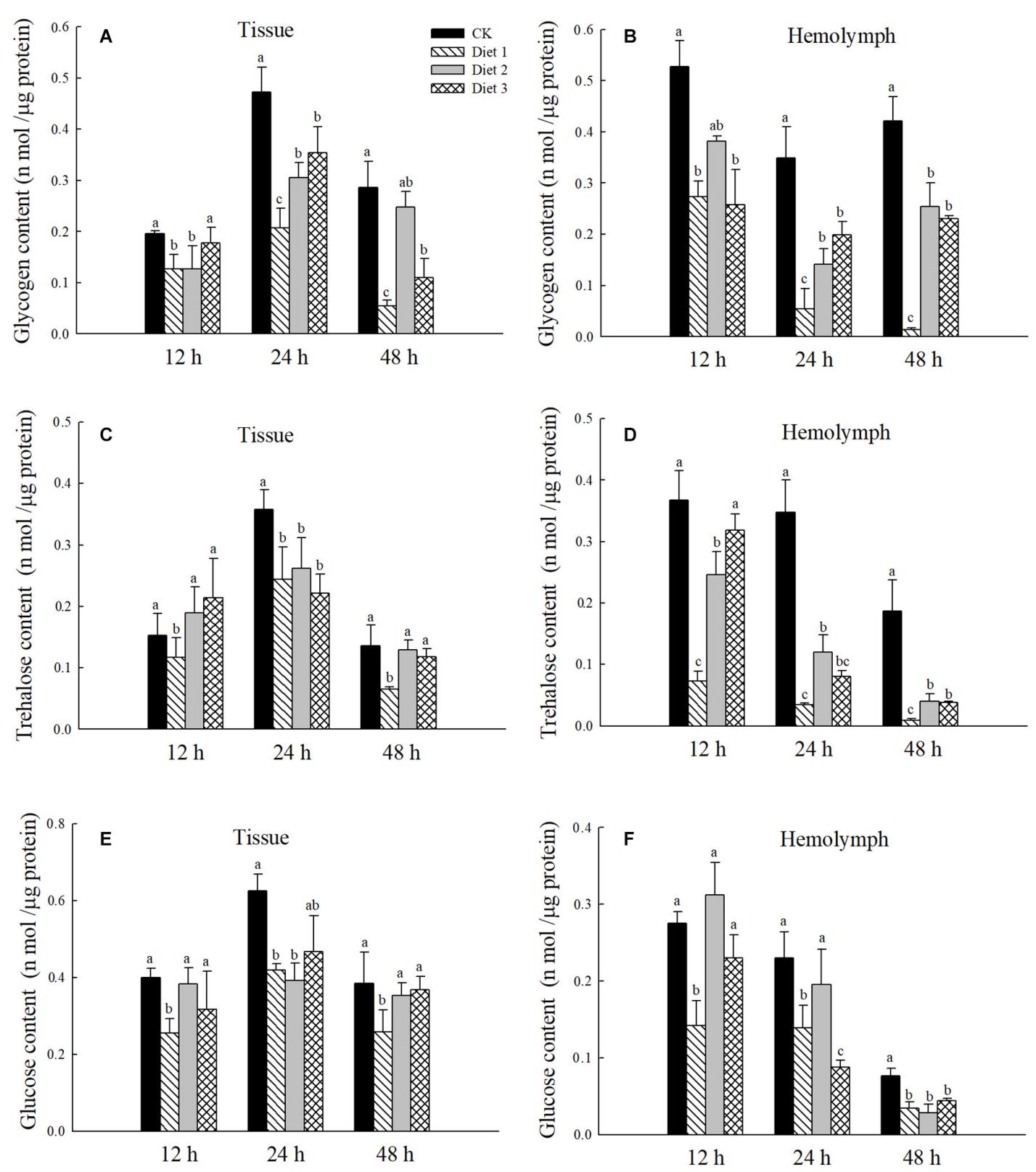

FIGURE 1 | After 12, 24, and 48 h of fed with three kinds of artificial feedstuffs, the sugar content in the larval tissue and hemolymph of $H$. axyridis. (A) The glycogen content in the tissue. (B) The trehalose content in the tissue. (C) The glucose content in the tissue. (D) The glycogen content in the hemolymph. (E) The trehalose content in the hemolymph. (F) The glucose content in the hemolymph. Line bars represent standard error of the mean. Bars with different letters are significantly different (Tukey-Kramer tests, $P<0.05$ ). Numbers of samples for each treatment of hemolymph $=7$. Sample size for each treatment of tissue $=3$.

significant at the third and fourth instar and at the pupal stage $(P<0.05)$. On weight of with different lowercase letters are significantly different.

\section{Pre-oviposition Period, Fecundity, and Hatching Rate Indicators of $\boldsymbol{H}$. axyridis Adults}

The results presented in Figure 3 show that the different artificial diets had a significant effect on the pre- oviposition, egg production, and hatching rate of $H$. axyridis $(P<0.05)$. The pre-oviposition period on Diet $1(15.33 \pm 1.52$ days $)$ was longer than that of Diet 2 and Diet $3(13.33 \pm 1.17$ and $11.75 \pm 1.72$ days, respectively) (Figure 3A). Additionally, the fecundity (Figure 3B) and the incubation fertility (Figure 3C) of Diet 2 (483.50 \pm 70.88 eggs per female, $81.69 \pm 10.60 \%)$ and Diet $3(527.66 \pm 49.65$ eggs per female, $87.00 \pm 12.64 \%$ ) were significantly higher than those of Diet 1 individuals $(236.92 \pm 32.56$ eggs per female, $60.67 \pm 15.23 \%$ ). 


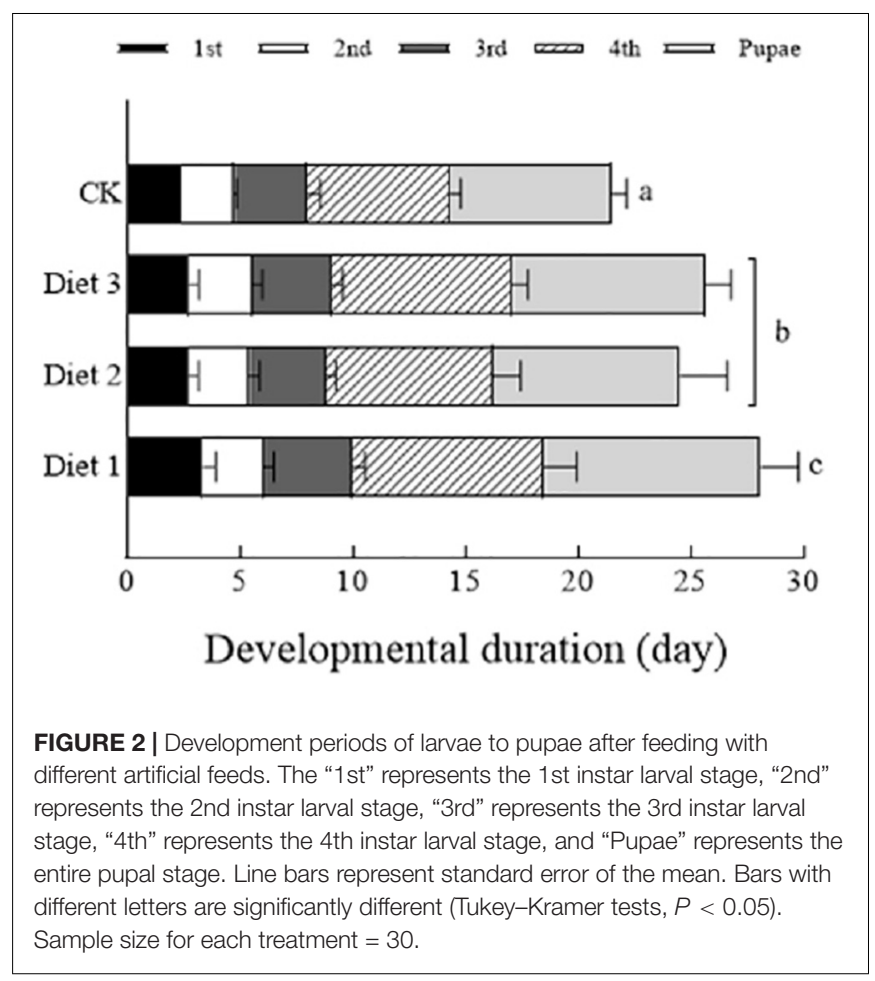

\section{Chemical Contents of Adults}

The glycogen content on Diet 2 and Diet 3 was significantly higher than that of Diet $1(P<0.05$; Figure $4 \mathrm{~A})$. In all time treatments, i.e., 48 and $72 \mathrm{~h}$ feeding on different artificial diets, trehalose and glycogen contents of the adults fed on Diet 2 and
Diet 3 were significantly higher than that of Diet $1(P<0.05$; Figures 4B,C).

In addition, we tested the content of associated chemical in adult $H$. axyridis after 48 and $72 \mathrm{~h}$ of feeding on different artificial diets. As is shown in Figure 5, after $72 \mathrm{~h}$ feeding on Diet 2 and Diet3 the ATP content of the adults was significantly higher than that on the adults fed with Diet 1 while there was no significant difference after feeding for $48 \mathrm{~h}(P<0.05$; Figure 5A). After 48 and $72 \mathrm{~h}$ feeding on Diet 2 and Diet 3, the fatty acid content was significantly higher than that of Diet $1(P<0.05$; Figure 5B); In this experiment, there was no significant difference among the total amino acid contents of the three groups after they had fed on an artificial diet for 48 and $72 \mathrm{~h}(P<0.05$; Figure 5C). Finally, the glycerol content of Diet 2 and Diet 3 individuals, after they had fed for 48 and $72 \mathrm{~h}$, was significantly higher than that of Diet 1 individuals $(P<0.05$; Figure 5D).

\section{Ovarian Development of the Adults}

Our results showed that the development of $H$. axyridis' ovaries that fed on aphids was obviously better than that of the artificialy-fed groups. The ovarian development of Diet 2 and Diet 3 insects was significantly better than that of Diet 1 insects (Figure 6).

\section{Relative Expression of $V g R$ and $V g s$ in H. axyridis Adults}

We tested the relative expression levels of the $V g R, V g 1$, and $V g 2$ genes in $H$. axyridis adult that fed on different artificial diets for 24 and 48 h. The $V g R$ gene expression in Diet 2 individuals was significantly higher than it was in Diet 1 individuals $(P<0.05$; Figure 7A). Additionally, there was no significant difference

TABLE 3 | Effect of different artificial diets on weight of Harmonia axyridis pupae.

\begin{tabular}{llccrr}
\hline Prescriptions & 1st $\mathbf{( m g )}$ & 2nd $(\mathbf{m g})$ & 3rd $(\mathbf{m g})$ & 4th (mg) & Pupae $(\mathbf{m g})$ \\
\hline Aphis medicaginis & $0.68 \pm 0.071 \mathrm{a}$ & $2.3 \pm 0.90 \mathrm{a}$ & $10 \pm 0.48 \mathrm{a}$ & $17.97 \pm 0.14 \mathrm{a}$ & $23.622 \pm 0.84 \mathrm{a}$ \\
Diet 1 & $0.63 \pm 0.64 \mathrm{a}$ & $1.2 \pm 0.41 \mathrm{c}$ & $4.1 \pm 0.42 \mathrm{~d}$ & $10.74 \pm 0.32 \mathrm{c}$ & $19.467 \pm 0.76 \mathrm{~b}$ \\
Diet 2 & $0.64 \pm 0.020 \mathrm{a}$ & $1.6 \pm 0.20 \mathrm{~b}$ & $8.7 \pm 0.35 \mathrm{a}$ & $15.58 \pm 0.24 \mathrm{~b}$ & $22.833 \pm 0.50 \mathrm{a}$ \\
Diet 3 & $0.66 \pm 0.03 \mathrm{a}$ & $1.9 \pm 0.37 \mathrm{ab}$ & $6.6 \pm 0.24 \mathrm{c}$ & $16.03 \pm 0.31 \mathrm{~b}$ & $21.967 \pm 0.16 \mathrm{a}$ \\
\hline
\end{tabular}
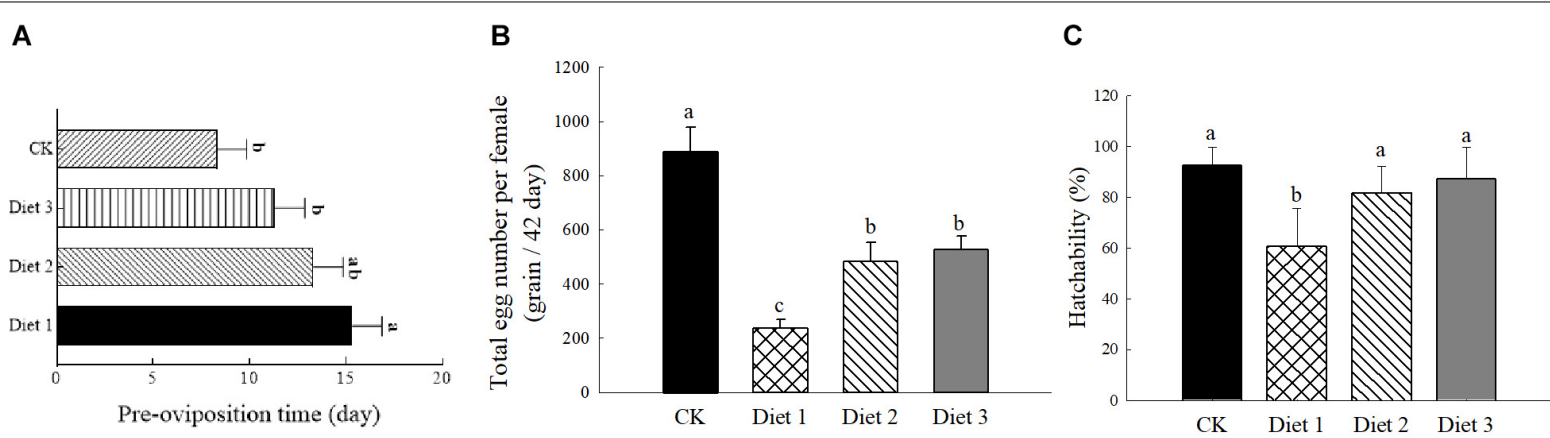

FIGURE 3 | Pre-laying period, egg-laying number and hatching rate of $H$. axyridis. (A) Pre-oviposition period, numbers of samples for each treatment $=36$. (B) In a single trial lasting 42 days of eggs laid by $H$. axyridis, numbers of samples for each treatment $=36$. (C) Hatching rate, numbers of samples for each treatment $=50$. Line bars represent standard error of the mean. Bars with different letters are significantly different (Tukey-Kramer tests, $P<0.05$ ). 


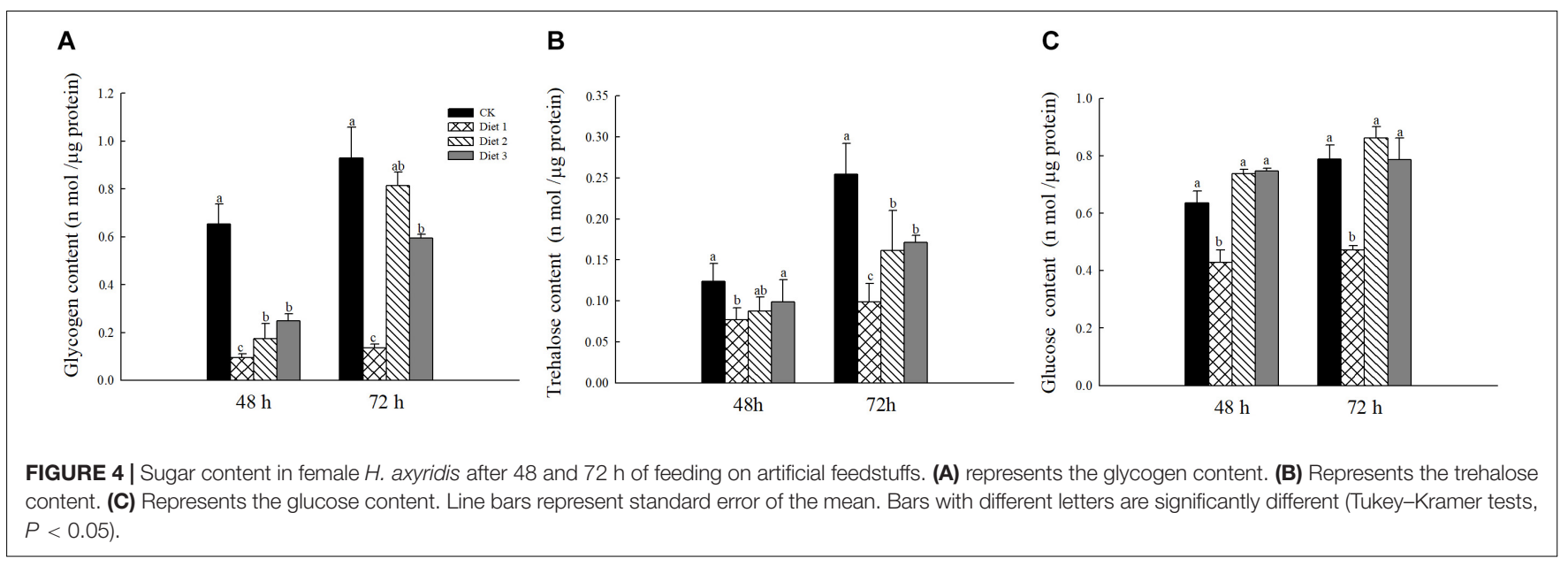

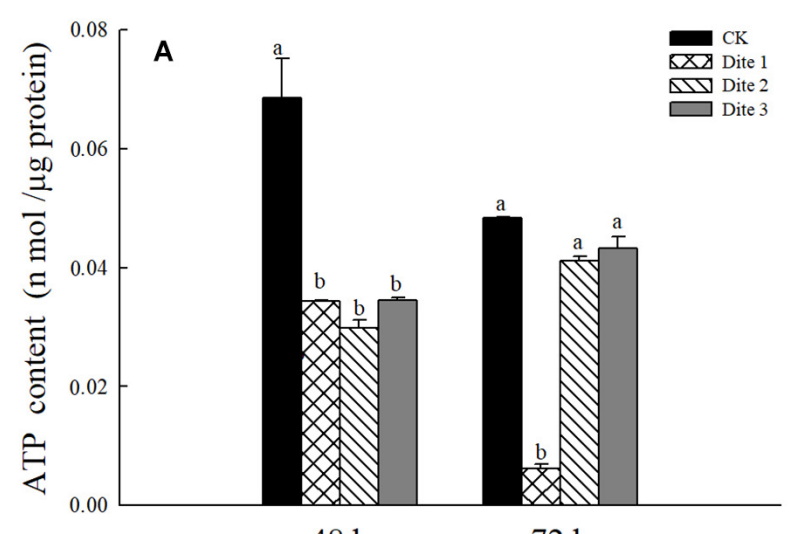

$48 \mathrm{~h}$

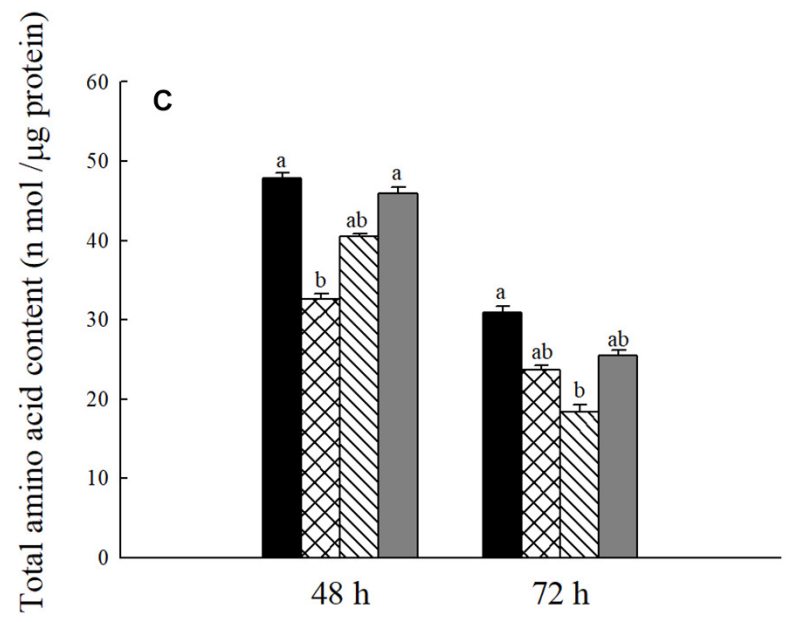

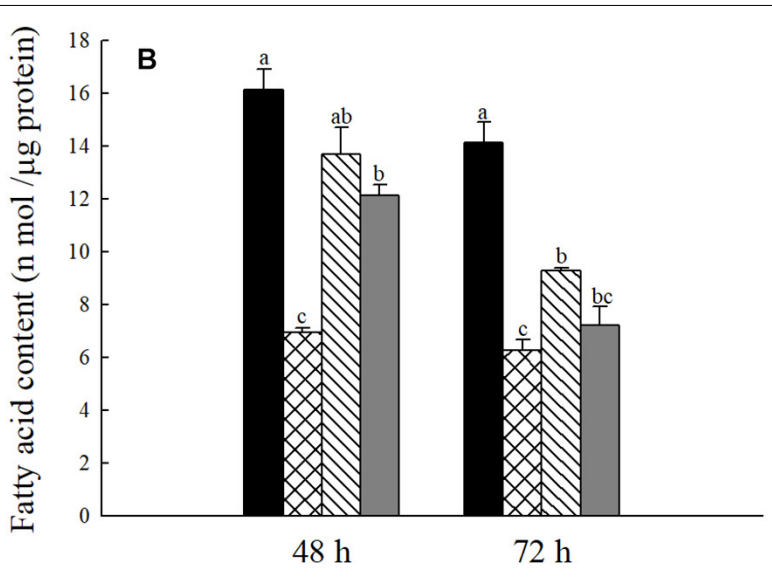

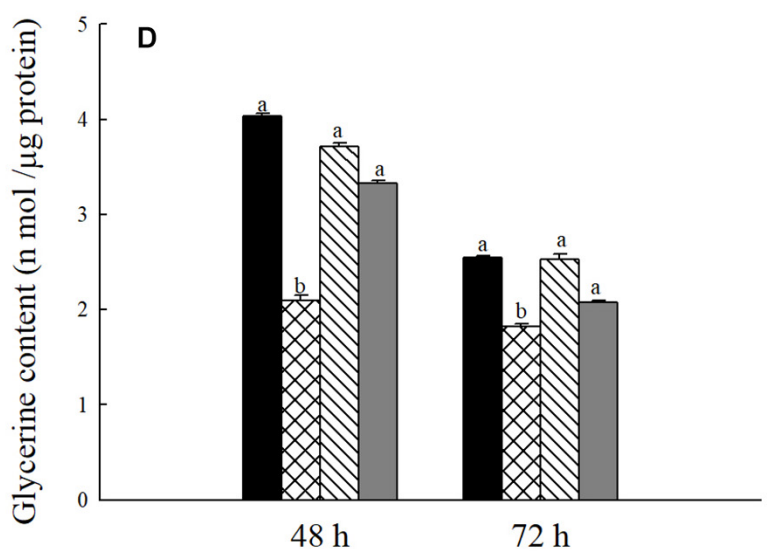

FIGURE 5 | Substance content in female H. axyridis after feeding on artificial feedstuffs for 48 and 72 h. (A) ATP content. (B) Fatty acid content. (C) Total amino acid content. (D) Glycerin content. Line bars represent standard error of the mean. Bars with different letters are significantly different (Tukey-Kramer tests, $P<0.05)$.

between the Diet 1 and Diet 3 groups. Regarding the relative expression of the $V g 1$ and $V g 2$ genes, the gene expression of Diet 2 and Diet 3 was significantly higher than that of Diet 1 insects. The gene expressions of all artificial feed groups were significantly lower than those of the $\mathrm{CK}$ group $(P<0.05$; Figures $7 \mathrm{~B}, \mathrm{C})$.

\section{DISCUSSION}

The results of this study showed that the trehalose, glucose, and glycogen contents in the hemolymph and tissues of larvae that fed on artificial Diet 2 and Diet 3 increased, indicating that the addition of glucose and trehalose has a certain impact on the 
A
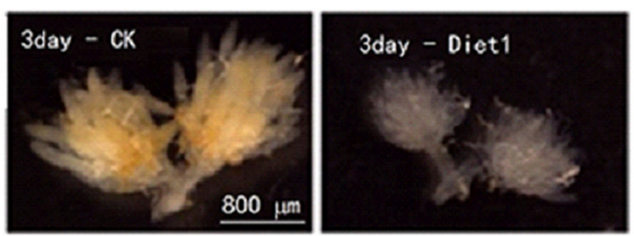

B

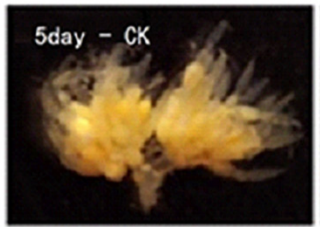

C

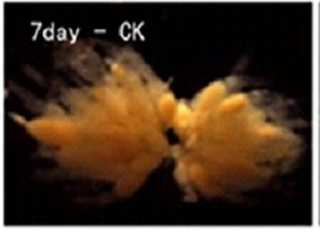

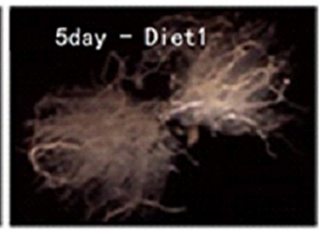

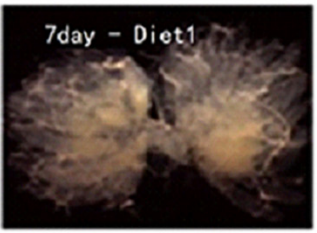

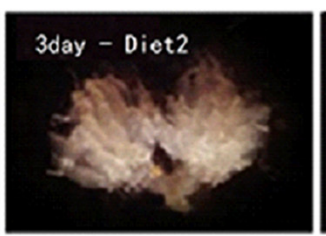
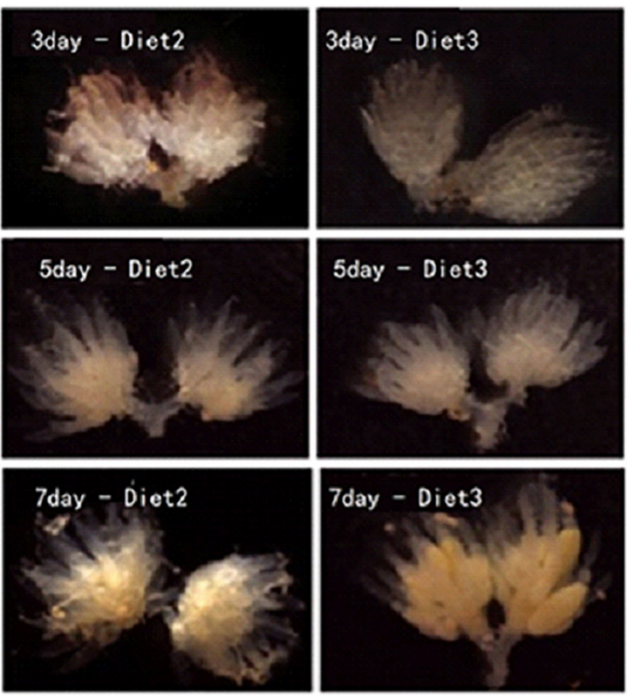

FIGURE 6 | Ovaries development of $H$. axyridis. Dissecting the ovaries of female $H$. axyridis in saline, after the wings were cut off, the back of the ladybird was gently made open. Remove non-reproductive tissues and organs such as fat body and digestive tract and intact ovaries could be seen at the end of the abdomen. (A) The ovarian anatomy of $H$. axyridis on the 3rd day after feeding. (B) The ovarian anatomy of $H$. axyridis on the 5 th day after feeding. (C) The ovarian anatomy of the $H$. axyridis after 7th day after feeding.
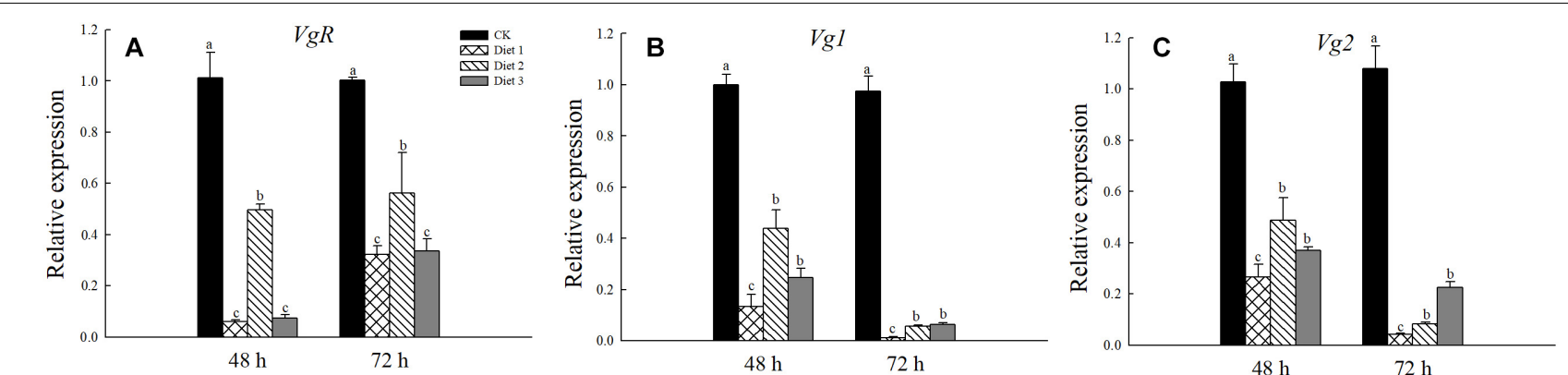

FIGURE 7 | Relative expression levels of $V g R, V g 1$, and $V g 2$ after fed for 48 and $72 \mathrm{~h}$. (A) Relative expression of $V g R$ gene. (B) Relative expression of $V g 1 g e n e$. (C) Relative expression of Vg2gene. Line bars represent standard error of the mean. Bars with different letters are significantly different (Tukey-Kramer tests, $P<0.05)$

life indicators of H. axyridis. Glycogen plays a regulatory role in insect development, affecting larval development and the ability to pupate (Yee et al., 2012; Puggioli et al., 2013). There are differences in the developmental time and viability of pupa and adult insects fed different artificial feedstuffs (Silva et al., 2009), this was confirmed by our study. In this study, the weight of larvae fed on Diet 2 and Diet 3 was significantly higher than that of those that fed on Diet 1. Additionally, the developmental period of larvae fed on Diet 2 and Diet 3 was extended significantly. Adding an appropriate amount of energy substances such as glucose or trehalose can help insects grow and develop. It has been reported that the health indicators of larvae affect the fecundity of adults (Leuck and Perkins, 1972).

It has been suggested that the growth and reproduction of insect populations are important indicators for analyzing and understanding insect artificial diet (Bellows et al., 1992). In this study, although the $H$. axyridis on Diet 1 reproduced and laid eggs, their fecundity was relatively lower than that of those fed on Diet 2 and Diet 3. This could be a result of the amount of nutrients and energy in their diet that were not enough for them to grow and reproduce. After adding glucose or trehalose to the pork liver diet, not only the pre-oviposition period shortened, but also the fecundity and fertility of the eggs increased. When newly hatched larvae have sufficient food resources, their mortality rate will decrease as they develop faster, which reduces damage during development (Lucas, 2005; Lebreton et al., 2015). The apparent benefits on the reproductive ability of insects that fed on artificial feedstuffs containing glucose or trehalose that were observed in the experiments described in this paper, are inconsistent with the results of a previous study, which reported that feeding Cydia pomonella with sugars (Siekmann et al., 2001) can extend their lives but cannot increase their or their eggs' fertility (Savary et al., 2019). However, the results of increased fertility obtained in this study are consistent with earlier reports 
of increased fertility caused by feeding sugar (Fadamiro and Heimpel, 2001). In parasitic bees, the benefits of glucose on health-related characteristics such as longevity and fertility are well-documented (Desouhant et al., 2010).

Trehalose has been reported as the dominant sugar in the insect hemolymph and other tissues (Van Handel, 1969) as it provides energy for targeted activities ( $\mathrm{Lu}$ et al., 2019). In our study, we detected that the ATP content in the Diet 2 and Diet 3 groups was significantly higher than that in the Diet 1 group. In addition, studies have reported that developing insect embryos use glycogen to generate ATP energy and produce biomolecules required for cell proliferation and differentiation to maintain the embryonic development (Tennessen et al., 2011). Further metabolic analysis has shown that glycogen stored in oocytes is consumed during embryogenesis (Matsuda et al., 2015). In this study, we found that the glycogen content of Diet 2 and Diet 3 adults was significantly higher than that of Diet 1 adults. This is relatively consistent with the results of the larval glycogen content. At the same time, the overall glucose content increased. The glucose increase could have been caused by the conversion of glycogen to glucose (Fraga et al., 2013). Prolonged starvation reduces trehalose and glucose levels (Schilman and Roces, 2008; Laparie et al., 2012). The ovary is a reproductive organ that plays a vital role in population reproduction (Koch, 2003). There is high correlation between trehalose levels and spawning. Decreasing trehalose levels will delay the production of oocysts (Huang and Lee, 2011). The results of the ovarian development map showed that the ovarian development of the Diet 1 group was significantly more stunted than that of the Diet 2 and Diet 3 groups. The development of the ovary can be based on the presence or absence of egg chambers, transparent ovaries or yolk deposition, etc., to determine whether the development is good at the normal development stage (Chen et al., 2015). This suggests that trehalose may be an important energy fuel during spawning.

The relative gene expression of $V g R, V g 1$, and $V g 2$ of insects that fed on Diet 2 and Diet 3 was significantly higher than that of those that fed on Diet 1. Oviposition is one of the most energy-demanding activities of adult female insects. During the development of oocytes, Vg is synthesized in the fat body, secreted into hemolymph, and enters developing oocytes through endocytosis mediated by the VgR (Tufail and Takeda, 2008). Therefore, the inadequate trehalose intake by the egg cells, which could inhibit the expression of $V g$, may be the main reason for the delayed oviposition of $H$. axyridis. Research on Drosophila has suggested that the higher expression rate of $V g$ (vitellogenin precursor) leads to an increase in egg maturation and fertility (Drapeau et al., 2006). Up to now, $V g$ has been widely studied in insects, with its direct physiological function being to provide nutrition for developing embryos (Tufail and Takeda, 2008). In our study, the addition of glucose or trehalose increased the $V g$ expression. Researchers have discovered that $V g$ is involved in the maturation and development of oocytes and is, therefore, a key factor in insect reproduction. Additionally, $V g$ has been studied in many insects, including Lepidoptera, Diptera, Hymenoptera, and Hemiptera (Raviv et al., 2006).

It is well-known that the activity of any insect is closely associated with its energy metabolism (Wong et al., 2016); additionally, the metabolism of fatty and amino acids affects the release of insect hormones (Van der Horst, 2003). Owing to the limited ability of the ovaries to synthesize lipids, the formation and mobilization of lipid reserves in the fat body is also critical for egg maturation. It has been reported that glucose is not only a major energy source, but also promotes the synthesis of most molecules such as amino acids, nucleotides, and fatty acids (Saltiel and Kahn, 2001). In our study, the fatty acid content of adult $H$. axyridis increased after adding glucose or trehalose to their diets (Figure 5B), which could also explain their improved ovarian development and fertility. During the development of insect oocytes, the developing oocytes accumulate a large amount of energy reserves from the hemolymph, such as lipids and proteins; essentially, reserves in the fat body that are essential for the development and reproduction of adults are mobilized (Tufail and Takeda, 2008). Excess glucose obtained from the diet is stored as branched-chain polysaccharide glycogen or as triglycerides in the body to satisfy future energy needs (Saltiel and Kahn, 2001; Chng et al., 2017). In this study, the glycerol content of the insects increased with the consumption of artificial feedstuff containing glucose or trehalose, indicating that the proper adjustment of the stored energy's anabolism and catabolism is critical to preserve the insect's metabolic balance throughout its life cycle (Mattila and Hietakangas, 2017). Moreover, studies have shown that insects with insufficient energy supply mobilize glycogen and triglycerides stored in their fat bodies (Bede et al., 2007; Konuma et al., 2012; Park et al., 2013). The lipid reserves of hungry females gradually decrease, while the lipid reserves of hungry males remain stable, indicating that nutrient reserves (lipids and glycogen) may be used when females spawn (Fadamiro et al., 2005). The fat content and fatty acid composition of insects depend on the composition of their feedstuffs and on the feeding conditions (Van Broekhoven et al., 2015), it follows that larvae fed low nutritional quality foods may use their fat reserves as energy, thereby reducing their fat content (St-Hilaire et al., 2007).

Therefore, the selection of a suitable artificial diet as larval food is the basis for the breeding success of $H$. axyridis. Research has indicated that there is an energetic cost to the act of reproduction (Wu et al., 2008) and several studies have shown that sugar has a positive effect on insect survival or fertility (Fadamiro and Heimpel, 2001). In addition, glucose increases mating events (Lebreton et al., 2015), which may contribute to the increase in spawning. Moreover, studies have shown that glucose can promote gastrointestinal motility, intestinal transport, and excretion (Chng et al., 2017), although these topics require further study.

\section{CONCLUSION}

Our results demonstrated that glucose and trehalose contributed to the growth, development and reproduction of $H$. axyridis, which may be due to their roles in energy. The reproduction of $H$. axyridis was elevated with addition of glucose and trehalose in our study. Adult reproduction depends on energy consumption and accumulation in the early stages of insect development, and 
the more is energy, the strong is reproduction. Therefore, the selection of suitable artificial diet as larval food is the basis for the success of $H$. axyridis breeding.

\section{DATA AVAILABILITY STATEMENT}

All datasets generated for this study are included in the article/supplementary material.

\section{AUTHOR CONTRIBUTIONS}

SGW and SW conceived the design and manuscript structure design. YL, YKL, YTL, SSW, and MZ contributed to the current articles collection and trehalose metabolism genes' analysis. YL,

\section{REFERENCES}

Bass, C., Denholm, I., Williamson, M. S., and Nauen, R. (2015). The global status of insect resistance to neonicotinoid insecticides. Pestic. Biochem. Physiol. 121, 78-87. doi: 10.1016/j.pestbp.2015.04.004

Bede, J. C., McNeil, J. N., and Tobe, S. S. (2007). The role of neuropeptides in caterpillar nutritional ecology. Peptides 28, 185-196. doi: 10.1016/j.peptides

Bellows, T. S., Van Driesche, R. G., and Elkinton, J. S. (1992). Life-Table construction and analysis in the evaluation of natural enemies. Annu. Rev. Entomol. 37, 587-612. doi: 10.1146/annurev.en.37.010192.003103

Bonte, M., Samih, M. A., and Clercq, P. D. (2010). Development and reproduction of Adalia bipunctata on factitious and artificial foods. Biocontrol. 55, 485-491. doi: 10.1007/s10526-010-9266-1

Brown, P. M. J., Thomas, C. E., Lombaert, E., Jeffries, D. L., Estoup, A., and Handley, L. J. L. (2011). The global spread of Harmonia axyridis (Coleoptera: Coccinellidae): distribution, dispersal and routes of invasion. Biocontrol. 56, 623-641. doi: 10.1007/s10526-011-9379-1

Castane, C., and Zapata, R. (2005). Rearing the predatory bug Macrolophus caliginosus on a meat based diet. Biocontrol 34, 66-72. doi: 10.1016/j.biocontrol

Castro, C. F., Almeida, L. M., and Penteado, S. R. C. (2011). The impact of temperature on biological aspects and life table of Harmonia axyridis (Pallas) (Coleoptera: Coccinellidae). Fla. Entomol. 94, 923-932. doi: 10.2307/23065850

Chen, J., Wu, C. J., Zhang, Q. W., Ma, Z., Sun, H. K., and He, Y. Z. (2015). Ovarian development and oogenesis of Harmonia axyridis Pallas. J. Plant Prot. 42, 237-243.

Cheng, Y., Zhi, J., Li, F., Li, W., and Zhou, Y. (2018). Improving the artificial diet for adult of seven spotted ladybird beetle Coccinella septempunctata L. (Coleoptera: Coccinellidae) with orthogonal design. Bull. Entomol. Res. 108, 337-343. doi: 10.1017/S0007485317000797

Chng, W. A., Hietakangas, V., and Lemaitre, B. (2017). Physiological adaptations to sugar intake: new paradigms from Drosophila melanogaster. Trends Endocrinol. Metab. 28, 131-142. doi: 10.1016/j.tem.2016.11.003

Cohen, A. C. (2001). Formalizing insect rearing and artificial diet technology. Ame Entomol. 47, 198-206. doi: 10.1093/ae/47.4.198

Denno, R. F., and Fagan, W. F. (2003). Might nitrogen limitation promote omnivory among carnivorous arthropods? Comment. Ecology 84, 2522-2531. doi: 10.1890/09-2080.1

Desouhant, E., Lucchetta, P., Giron, D., and Bernstein, C. (2010). Feeding activity pattern in a parasitic wasp when foraging in the field. Ecol. Res. 25, 419-428. doi: 10.1007/s11284-009-0671-9

Drapeau, M. D., Albert, S., Kucharski, R., Prusko, C., and Maleszka, R. (2006). Evolution of the yellow/major royal jelly protein family and the emergence of social behavior in honey bees. Genome Res. 16, 1385-1394. doi: 10.1101/gr. 5012006

Fadamiro, H. Y., Chen, L., Onagbola, E. O., and Graham, L. (2005). Lifespan and patterns of accumulation and mobilization of nutrients in the sugar-fed phorid
SW, and SGW wrote the manuscript. All authors contributed to the article and approved the submitted version.

\section{FUNDING}

This work was supported by National Key Research and Development Program of China (Grant No. 2017YFD0201000), Hangzhou Science and Technology Development Program of China (Grant No. 20190101A01), Beijing Key Laboratory of Environment-Friendly Management on Fruit Disease and Pests in North China (Grant No. BZ0432), Beijing Technology Program (Grant No. D171100001617003), Technical Innovation Program of Beijing Academy of Agricultural and Forest Science (Grant No. 20170107), and Youth Scientific Research Fund of Beijing Academy of Agricultural and Forestry Science (Grant No. QNJJ201725).

fly, Pseudacteon tricuspis. Physiolog. Entomol. 30, 212-224. doi: 10.1111/j.13653032.2005.00449.x

Fadamiro, H. Y., and Heimpel, G. E. (2001). Effects of Partial Sugar Deprivation on Lifespan and Carbohydrate Mobilization in the Parasitoid Macrocentrus grandii (Hymenoptera: Braconidae). Ann. Entomol. Soc. Am. 94, 909-916. doi: 10.1603/0013-8746(2001)094[0909:eopsdo]2.0.co;2

Fraga, A., Ribeiro, L., Lobato, M., Santos, V., Silva, J. R., Gomes, H., et al. (2013). Glycogen and Glucose Metabolism Are Essential for Early Embryonic Development of the Red Flour Beetle Tribolium castaneum. PLoS One 8:e65125. doi: 10.1371/journal.pone.0065125

Garratt, J., and Kennedy, A. (2006). Use of models to assess the reduction in contamination of water bodies by agricultural pesticides through the implementation of policy instruments: a case study of the Voluntary Initiative in the UK. Pest Manag. Sci. 62, 1138-1149. doi: 10.1002/ps.1284

Guo, J. Y., and Wan, F. H. (2001). Effect of three diets on development and fecundity of the ladybeetles Harmonia axyridis and Propylaea japonica. Chin. J. Biol. Cont. 17, 116-120. doi: 10.16409/j.cnki.2095-039x

Hansen, D. L., Brodsgaard, H. F., and Enkegaard, A. (1999). Life table characteristics of Macrolophus caliginosus preying upon Tetra urticae. Entomol. Exp. Appl. 9, 269-275.

Haque, M. A., Chen, J., Aldred, P., and Adhikari, B. (2015). Drying and denaturation characteristics of whey protein isolate in the presence of lactose and trehalose. Food Chem. 177, 8-16. doi: 10.1016/j.foodchem.2014.12.064

Huang, J. H., and Lee, H. J. (2011). RNA interference unveils functions of the hypertrehalosemic hormone on cyclic fluctuation of hemolymph trehalose and oviposition in the virgin female Blattella germanica. J. Insect Physiol. 57, 858-864. doi: 10.1016/j.jinsphys

Huang, J. J., Ding, B. J., Shu, X. H., and Liu, Y. H. (2015). Effects of different sugars on longevity and egg mature of Microplitis mediator. J. Environ. Entomol. 37, $617-622$.

Juen, A., Hogendoorn, K. M. G., Schmidt, O., and Keller, M. A. (2012). Analysing the diets of invertebrate predators using terminal restriction fragments. J. Pest Sci. 85, 89-100. doi: 10.1007/s10340-011-0406-x

Katsarou, I., Margaritopoulos, J. T., Tsitsipis, J. A., Perdikis, D. C., and Zarpas, K. D. (2005). Effect of temperature on development, growth and feeding of Coccinella septempunctata and Hippodamia convergens reared on the tobacco aphid, Myzus persicaenicotianae. Biocontrol 50, 565-588. doi: 10.1007/s10526004-2838- 1

Kavi, L. A., Kaufman, P. E., and Scott, J. G. (2014). Genetics and mechanisms of imidacloprid resistance in house flies. Pestic. Biochem. Physiol. 109, 64-69. doi: 10.1016/j.pestbp.2014.01.006

Koch, R. L. (2003). The multicolored Asian lady beetle, Harmonia axyridis: a review of its biology, uses in biological control, and non-target impacts. J. Insect Sci. 3:32. doi: $10.1093 /$ jis/3.1.32

Konuma, T., Morooka, N., Nagasawa, H., and Nagata, S. (2012). Knockdown of the adipokinetic hormone receptor increases feeding frequency in the two-spotted 
cricket Gryllus bimaculatus. Endocrinology 153, 3111-3122. doi: 10.1210/en. 2011-1533

Laparie, M., Larvor, V., Frenot, Y., and Renault, D. (2012). Starvation resistance and effects of diet on energy reserves in a predatory ground beetle (Merizodus soledadinus; Carabidae) invading the Kerguelen Islands. Comp. Biochem. Physiol. A. Mol. Integr. Physiol. 161, 122-129. doi: 10.1016/j.cbpa.2011. 09.011

Lebreton, S., Trona, F., Borrero-Echeverry, F., Bilz, F., Grabe, V., Becher, P. G., et al. (2015). Feeding regulates sex pheromone attraction and courtship in Drosophila females. Sci. Rep. 5:13132. doi: 10.1038/srep13132

Leuck, D. B., and Perkins, W. D. (1972). A method of estimating fall armyworm progeny reduction when evaluating control achieved by host-plant resistance. J. Econ. Entomol. 65, 482-483. doi: 10.1093/jee/65.2.482

Li, G. H., Pang, Y., Chen, Q., Su, Z. J., and Wen, X. Z. (2002). Studies on the artificial diet for beet armyworm, Spodoptera exigua. Chin. J. Biol. Cont. 18, 132-134. doi: 10.16409/j.cnki.2095-039x.2002.03.008

Liu, H. L., Zheng, L. M., Liu, Q. Q., Quan, F. S., and Zhang, Y. (2013). Studies on the transcriptomes of non-model organisms. Hereditas 35, 955-970. doi: 10.3724/sp.j.1005.2013.00955

Livak, K. J., and Schmittgen, T. D. (2001). Analysis of relative gene expression data using real-time quantitative PCR and the 2-11CT method. Methods 25, 402-408. doi: 10.1006/meth

Lu, K., Wang, Y., Chen, X., Zhang, X., Li, W., Cheng, Y., et al. (2019). Adipokinetic hormone receptor mediates trehalose homeostasis to promote vitellogenin uptake by oocytes in Nilaparvata lugens. Front. Physiol. 9:1904. doi: 10.3389/ fphys.2018.01904

Lu, Y., Wu, K., Jiang, Y., Guo, Y., and Desneux, N. (2012). Widespread adoption of Bt cotton and insecticide decrease promotes biocontrol services. Nature 487, 362-365. doi: 10.1038/nature11153

Lucas, É (2005). Intraguild predation among aphidophagous predators. Eur. J. Entomol. 102, 351-364. doi: 10.14411/eje.2005.052

Luo, S. P., Naranjo, S. E., and Wu, K. M. (2014). Biological control of cotton pests in China. Biol. Control. 68, 6-14. doi: 10.1016/j.biocontrol.2013.06.004

Majerus, M., Strawson, V., and Roy, H. (2006). The potential impacts of the arrival of the harlequin ladybird, Harmonia axyridis (Pallas) (Coleoptera: Coccinellidae), in Britain. J. Econ. Entomol. 31, 207-215. doi: 10.1111/j.13652311.2006.00734.x

Matsuda, H., Yamada, T., Yoshida, M., and Nishimura, T. (2015). Flies without trehalose. J. Biol. Chem. 290, 1244-1255. doi: 10.1074/jbc.M114.619411

Mattila, J., and Hietakangas, V. (2017). Regulation of carbohydrate energy metabolism in Drosophila melanogaster. Genetics 207, 1231-1253. doi: 10.1534/ genetics.117.199885

Michaud, J. P. (2002). Invasion of the Florida citrus ecosystem by Harmonia axyridis (Coleoptera: Coccinellidae) and asymmetric competition with a native species, Cycloneda sanguinea. Environ. Entomol. 31, 827-835. doi: 10.1603/ 0046-225X-31.5.827

Park, M. S., Park, P., and Takeda, M. (2013). Roles of fat body trophocytes, mycetocytes and urocytes in the American cockroach, Periplaneta americana under starvation conditions: an ultrastructural study. Arthropod Struct. Dev. 42, 287-295. doi: 10.1016/j.asd.2013.03.004

Puggioli, A., Balestrino, F., Damiens, D., Lees, R. S., Soliban, S. M., Madakacherry, O., et al. (2013). Efficiency of three diets for larval development in mass rearing Aedes albopictus (Diptera: Culicidae). J. Med. Entomol. 50, 819-825. doi: 10.1603/me13011

Puinean, A. M., Denholm, I., Millar, N. S., Nauen, R., and Williamson, M. S. (2010). Characterisation of imidacloprid resistance mechanisms in the brown planthopper, Nilaparvata lugens Stål (Hemiptera: Delphacidae). Pestic. Biochem. Physiol. 97, 129-132. doi: 10.1016/j.pestbp.2009.06.008

Raviv, S., Parnes, S., Segall, C., Davis, C., and Sagi, A. (2006). Complete sequence of Litopenaeus vannamei (Crustacea: Decapoda) vitellogenin cDNA and its expression in endocrinologically induced sub-adult females. Gen. Comp. Endocrinol. 145, 39-50. doi: 10.1016/j.ygcen.2005.06.009

Saddiq, B., Shad, S. A., Aslam, M., Ijaz, M., and Abbas, N. (2015). Monitoring resistance of Phenacoccus solenopsis Tinsley (Homoptera: pseudococcidae) to new chemical insecticides in Punjab, Pakistan. Crop Prot. 74, 24-29. doi: 10.1016/j.cropro.2015.03.026

Saltiel, A. R., and Kahn, C. R. (2001). Insulin signalling and the regulation of glucose and lipid metabolism. Nature 414, 799-806. doi: 10.1038/414799a
Savary, S., Willocquet, L., Pethybridge, S. J., Esker, P., McRoberts, N., and Nelson, A. (2019). The global burden of pathogens and pests on major food crops. Nat. Ecol. Evol. 3, 430-439. doi: 10.1038/s41559-018-0793-y

Schilman, P. E., and Roces, F. (2008). Haemolymph sugar levels in a nectar-feeding ant: dependence on metabolic expenditure and carbohydrate deprivation. J. Comp. Physiol. B. 178, 157-165. doi: 10.1007/s00360-007-0207-y

Schmidt, J. M., Sebastian, P., Wilder, S. M., and Rypstra, A. L. (2012). The nutritional content of prey affects the foraging of a generalist arthropod predator. PLoS One 7:e49223. doi: 10.1371/journal.pone.0049223

Shi, Z. K., Wang, S., Wang, S. G., Zhang, L., Xu, Y. X., Guo, X. J., et al. (2017). Effects of starvation on the carbohydrate metabolism in Harmonia axyridis (Pallas). Biol. Open. 15 6, 1096-1103. doi: 10.1242/bio.025189

Siekmann, G., Tenhumberg, B., and Keller, M. A. (2001). Feeding and survival in parasitic wasps: sugar concentration and timing matter. Oikos 95, 425-430. doi: 10.1034/j.1600-0706.2001.950307.x

Silva, R. B., Zanuncio, J. C., Serrão, J. E., Lima, E. R., Figueiredo, M. L. C., and Cruz, I. (2009). Suitability of different artificial diets for development and survival of stages of the predaceous ladybird beetle Eriopis connexa. Phytoparasitica 37, 115-123. doi: 10.1007/s12600-008-0015-2

St-Hilaire, S., Cranfill, K., McGuire, M. A., Mosley, E. E., Tomberlin, J. K., Newton, L., et al. (2007). Fish offal recycling by the black soldier fly produces a foodstuff high in omega-3 fatty acids. J. World Aquac. Soc. 38, 309-313. doi: 10.1111/j. 1749-7345.2007.00101.x

Tang, B., Chen, J., Yao, Q., Pan, Z., Xu, W., Wang, S., et al. (2010). Characterization of a trehalose-6-phosphate synthase gene from Spodoptera exigua and its function identification through RNA interference. J. Insect Physiol. 56, 813-821. doi: 10.1016/j.jinsphys.2010.02.009

Tang, B., Xu, Q., Zou, Q., Fang, Q., Wang, S. G., and Ye, G. Y. (2012). Sequencing and characterization of glycogen synthase and glycogen phosphorylase genes from Spodoptera exigua and analysis of their function in starvation and excessive sugar intake. Arch. Insect Biochem. Physiol. 80, 42-62. doi: 10.1002/ $\operatorname{arch} .21027$

Tennessen, J. M., Baker, K. D., Lam, G., Evans, J., and Thummel, C. S. (2011). The Drosophila estrogen-related receptor directs a metabolic switch that supports developmental growth. Cell Metab. 13, 139-148. doi: 10.1016/j.cmet.2011.01. 005

Thompson, S. N. (2003). Trehalose - the insect 'blood' sugar. Adv. Insect. Physiol $31,205-285$.

Tufail, M., Naeemullah, M., Elmogy, M., Sharma, P. N., Takeda, M., and Nakamura, C. (2010). Molecular cloning, transcriptional regulation, and differential expression profiling of vitellogenin in two wing-morphs of the brown planthopper, Nilaparvata lugens Stål (Hemiptera: Delphacidae). Insect Mol. Biol. 19, 787-798. doi: 10.1111/j.1365-2583.2010.01035.x

Tufail, M., and Takeda, M. (2008). Molecular characteristics of insect vitellogenins. J. Insect Physiol. 54, 1447-1458. doi: 10.1016/j.jinsphys.2008.08.007

Van, J. C. (2012). The state of commercial augmentative biological control: plenty of natural enemies, but a frustrating lack of uptake. Biocontrol 57, 1-20. doi: 10.1007/s10526-011-9395-1

Van Broekhoven, S., Oonincx, D. G., van Huis, A., and van Loon, J. J. (2015). Growth performance and feed conversion efficiency of three edible mealworm species (Coleoptera: Tenebrionidae) on diets composed of organic by-products. J. Insect Physiol. 73, 1-10. doi: 10.1016/j.jinsphys.2014.12.005

Van der Horst, D. J. (2003). Insect adipokinetic hormones: release and integration of flight energy metabolism. Comp. Biochem. Physiol. B. Biochem. Mol. Biol. 136, 217-226. doi: 10.1016/s1096-4959(03)00151-9

Van Handel, E. (1969). Metabolism of hexoses in the intact mosquito: exclusion of glucose and trehalose as intermediates. Comp. Biochem. Physiol. 29, 413-421. doi: 10.1016/0010-406x(69)91760-5

Vaulont, S., Vasseur-Cognet, M., and Kahn, A. F. (2000). Glucose regulation of gene transcription. J. Biol. Chem. 275, 555-558. doi: 10.1074/jbc.R0000 16200

Wang, C., Cao, Y., Wang, Z., Yin, Y., Peng, G., Li, Z., et al. (2007). Differentiallyexpressed glycoproteins in Locusta migratoria hemolymph infected with Metarhizium anisopliae. J. Invertebr. Pathol. 96, 230-236. doi: 10.1016/j.jip. 2007.05.012

Wilder, S. M., Holway, D. A., Suarez, A. V., and Eubanks, M. D. (2011). Macronutrient content of plant-based food affects growth of a carnivorous arthropod. Ecology 92, 325-332. doi: 10.1890/10-0623.1 
Wong, S. C., Oksanen, A., Mattila, A. L., Lehtonen, R., Niitepõld, K., and Hanski, I. (2016). Effects of ambient and preceding temperatures and metabolic genes on flight metabolism in the Glanville fritillary butterfly. J. Insect Physiol. 85, 23-31. doi: 10.1016/j.jinsphys.2015.11.015

Wu, H. P., Meng, L., and Li, B. P. (2008). Effects of feeding frequency and sugar concentrations on lifetime reproductive success of Meteorus pulchricornis (Hymenoptera: Braconidae). Biol. Cont. 45, 353-359. doi: 10.1016/j.biocontrol. 2008.01.017

Yang, H., Xiong, J. W., and Zhang, F. (2013). Advances of artificial diet for Harminia axyridis. J. Mou. Agr. Biol. 22, 169-172. doi: 10.15958/j.cnki. sdnyswxb.2003.02.016

Yee, D. A., Juliano, S. A., and Vamosi, S. M. (2012). Seasonal photoperiods alter developmental time and mass of an invasive mosquito, Aedes albopictus (Diptera: Culicidae), across its north-south range in the United States. J. Med. Entomol. 49, 825-832. doi: 10.1603/me11132

Youn, Y. N., Seo, M. J., Shin, J. G., Jang, C., and Yu, Y. M. (2003). Toxicity of greenhouse pesticides to multicolored Asian lady beetles, Harmonia axyridis (Coleoptera:Coccinellidae). Biocontrol 28:170. doi: 10.1016/s1049-9644(03) 00098-7

Zazycki, L. C. F., Semedo, R. E. S., Silva, A., Bisognin, A. Z., Bernardi, O., Garcia, M. S., et al. (2015). Biology and fertility life table of Eriopis connexa,
Harmonia axyridis and Olla v-nigrum (Coleoptera: Coccinellidae). Braz. J. Biol. 75, 969-973. doi: 10.1590/1519-6984.03814

Zhang, L. S., Chen, H. Y., and Li, B. P. (2014). Mass rearing and utilization of insect natural enemies, 1st Edn. Beijing: China Agriculture Scientech Press.

Zhang, T., Zhang, G., Zeng, F., Mao, J., Liang, H., and Liu, F. (2017). Molecular cloning of the vitellogenin gene and the effects of vitellogenin protein expression on the physiology of Harmonia axyridis (Coleoptera: Coccinellidae). Sci. Rep. 7:13926. doi: 10.1038/s41598-01714339-3

Conflict of Interest: The authors declare that the research was conducted in the absence of any commercial or financial relationships that could be construed as a potential conflict of interest.

Copyright (c) $2020 \mathrm{Li}$, Wang, Liu, Lu, Zhou, Wang and Wang. This is an open-access article distributed under the terms of the Creative Commons Attribution License (CC BY). The use, distribution or reproduction in other forums is permitted, provided the original author(s) and the copyright owner(s) are credited and that the original publication in this journal is cited, in accordance with accepted academic practice. No use, distribution or reproduction is permitted which does not comply with these terms. 